\title{
SURFACE ROUGHNESS AFTER DRILLING OF LAMINATED CHIPBOARD
}

\begin{abstract}
In this study the eighteen tests of tool durability for different values of the analyzed cutting parameters were carried out. Based on the results of investigations, the influence of selected cutting parameters on the machined surface quality was determined. Mathematical models based on analysis of variance (ANOVA), allowing to estimate the surface quality in the cutting process were proposed.
\end{abstract}

Keywords: drilling, tool wear, surface quality, laminated chipboard

\section{Introduction}

During drilling, there is a delamination of the laminate around the hole. The quality of the cut surface is related to the machining conditions, parameters of the cutting tool geometry [1]. Many research works related to the effect of cutting parameters (such as cutting speed, feed rate) on the quality of the machined surface around the hole were carried out. A speed and feed rate has a significant influence on the delamination [2,6]. It was also found that higher rotational speed reduces the tendency of delamination. Gaitonde and Karnik [3] determined the effect of processing conditions on delamination factor $F_{d}$ and they found that the feed rate and spindle speed were the most important factors in minimizing $F_{d}$ both the entrance and exit of drilling holes in the MDF. Palanikumar and Prakash [4] showed that the size delamination during drilling MDF board can be reduced by using a low feed rate. Tsao [5] found that the feed rate and spindle speed are the dominant cutting parameters which influence the delamination.

\section{Material and methods}

The experiments were performed on pre-laminated particle board (PB) $8 \%$ moisture containing and density of $670 \mathrm{~kg} / \mathrm{m}^{3}$, with the thickness of $12 \mathrm{~mm}$ using Faba HW drills with diameter of $10 \mathrm{~mm}$ on Buselatto JET $130 \mathrm{CNC}$ verti-

\footnotetext{
1 Autor do korespondencji/corresponding author: Krzysztof Szwajka, Rzeszow University of Technology, 4 Kwiatkowskiego Street, 37-450 Stalowa Wola, Poland, tel.: (15) 8448219, e-mail: kszwajka@prz.edu.pl
} 
cal machining centre with a maximum spindle speed of $18.000 \mathrm{rpm}$. The quality of the machined surface for the new and the wear tools are shown in fig. 1. The properties of tested PB composites are as follow: $R_{m}=0.43 \mathrm{MPa}, E=2.45 \mathrm{GPa}$. Processing parameters of the tests were: feed rate $-0.2 ; 0.25$ and $0.3 \mathrm{~mm} / \mathrm{rev}$; cutting speed $-125-377 \mathrm{~m} / \mathrm{min}$. Tests were performed until the maximum value of indicator of tool wear was found. Durability experiments consist of repetitive operations. In each test the 252 holes were drilled. Eighteen tests of the tool life investigation were carried out.
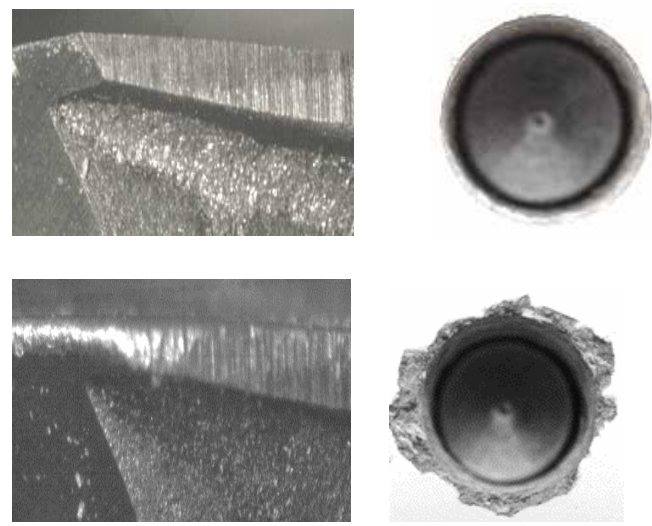

Fig. 1. The quality of the machined surface for new (top) and the wear (bottom) tools

\section{Measurements of delamination}

In studies as a tool wear indicator $V B_{\max }=0.2 \mathrm{~mm}$ was adopted. The measurement of tool wear was performed on the Mitutoyo TM microscope (fig. 2.) with dropped digital camera eyepiece with a resolution of $600 \mathrm{dpi}$, which allows for image archiving on a personal computer.
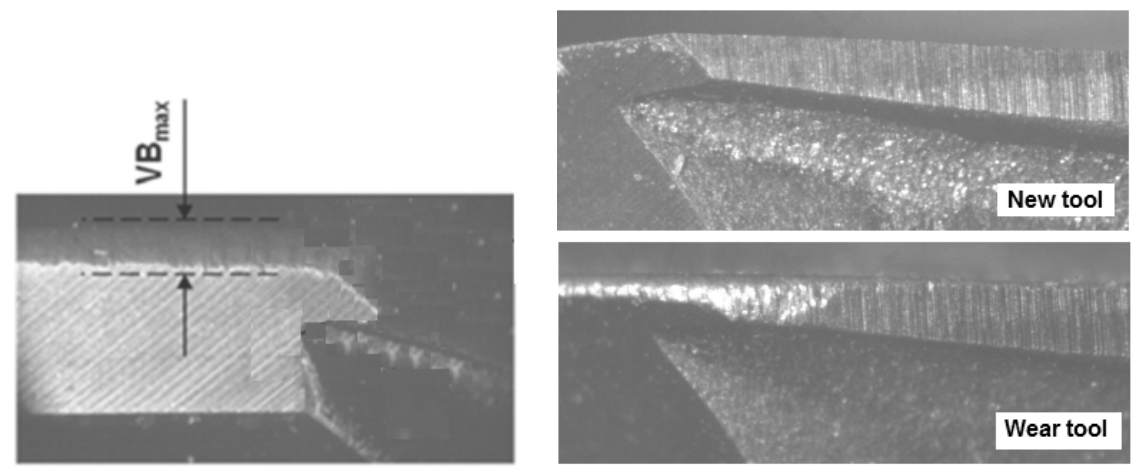

Fig. 2. Measurement of tool wear 
To determine the quality of the surface around the hole in the study it was decided to adopt the two most commonly used indicators: the maximum radius $R_{\max }$ of the laminate and torn surface area of the laminate $A$. The two ratios were determined at the entrance of the tool into the material workpiece. In this way two indicators: $A_{w e j}, R_{w e j}$ were determined. To determine the accepted indicators recorded images were processed in the LabView environment.

\section{The test results}

Figure 3. presents the results of the study, in which, with the help of ANOVA delamination area of the laminate at the entrance of the drill into the material $\left(A_{w e j}\right)$ and the maximum radius of delamination of laminate at the entrance of the drill into the material $\left(R_{w e j}\right)$, using three different feed rates $(f)$, five cutting speeds $\left(v_{c}\right)$ and four values of tool wear $\left(V B_{\max }\right)$ were analyzed. In order to determine the effect of tool wear on the cutting force and torque ranges of cutting tool wear was adopted as the independent variable $F_{i}$. The ranges of the independent variables $\left(F_{i}\right)$ used in the analysis of results are as follow: $F_{1}=0-0.095$; $F_{2}=0.10-0.15$ and $F_{3}=0.155-0.200$. For the present experiment, ANOVA analysis was conducted in STATISTICA program, which allows to evaluate the significance of the impact of three factors on the course of the controlled experiment. In this work the level of significance was $p=0.05$. The results of analysis (fig. 4.) reject the hypothesis about the lack of impact of factor $V B_{\max }$ on the area of delamination of laminate $\left(A_{w e j}\right)$. So, it can be noted that the value of tool wear significantly affects the process of laminate delamination, using as an indicator of measurement (to assess the delamination magnitude) - delamination area of the laminate $\left(A_{w e j}\right)$. Similar conclusions can be drawn in relation to the effect of cutting speed $\left(v_{c}\right)$. At the significance level the effect of cutting speed on the torn area of the laminate was also noticed. While the impact of the feed rate $(f)$ is statistically insignificant. Finally, the change of the value of cutting speed and wear significantly affects the area of the laminate delamination $\left(A_{w e j}\right)$, while a change in the feed rate has no significant effect. There was also observed a statistically

The results of analysis presented in the fig. 4. reject the hypothesis about the lack of influence of $V B_{\max }$ and $f$ on the maximum radius of delamination $\left(R_{w e j}\right)$. It can be noted that the values of tool wear and feed rate significantly affect the process of delamination, using as an indicator of measurement (to assess the magnitude of delamination) - maximum radius of delamination $\left(R_{w e j}\right)$. There was no effect of cutting speed on the maximum radius of delamination. In summary, the change of the value wear and feed rate significantly affects the maximum radius of delamination $\left(R_{w e j}\right)$. There was also observed statistically significant interaction between the studied factors.significant interaction between the studied factors. 

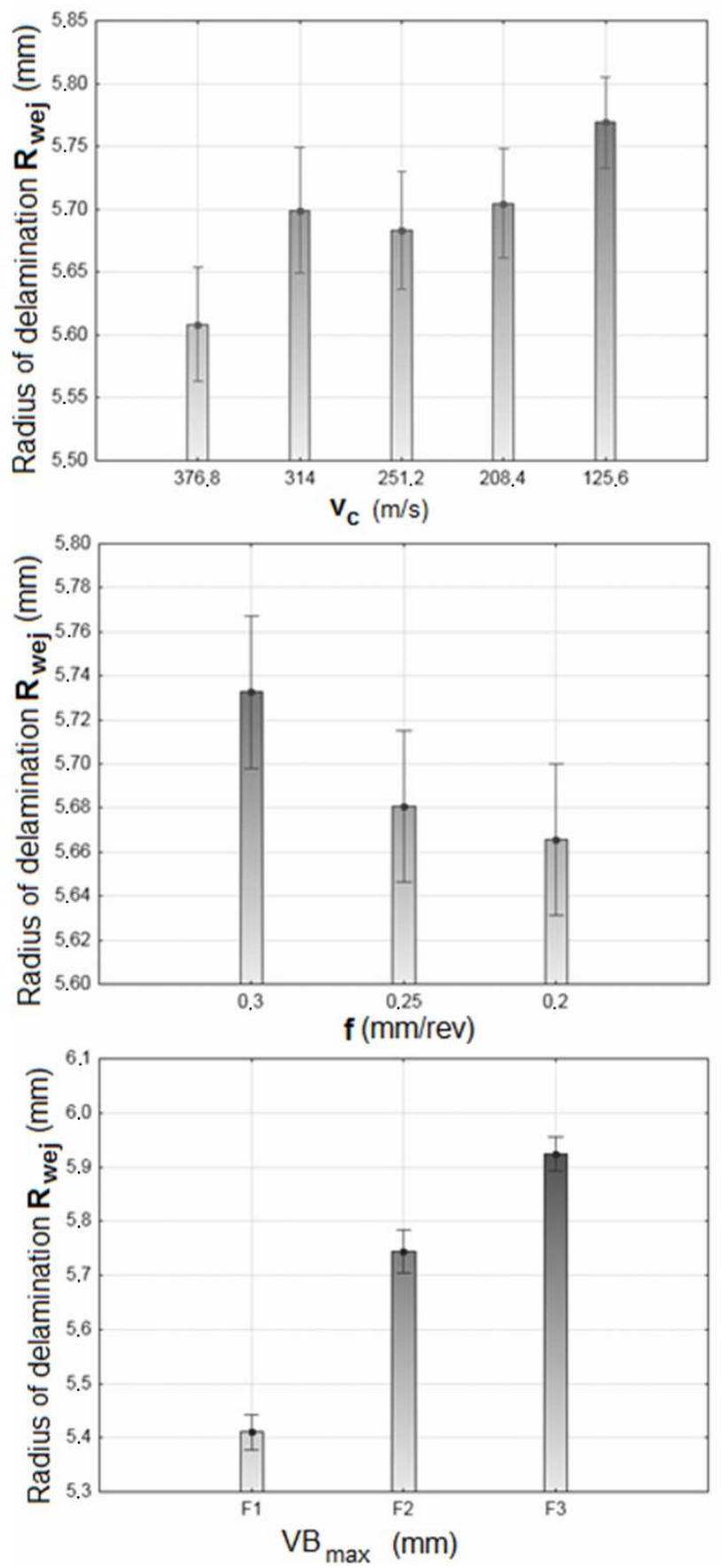

Fig. 3. The influence of cutting parameters on the value of the damage to the laminate surface at the entrance of the drill into the material $\left(A_{w e j}\right)$ 

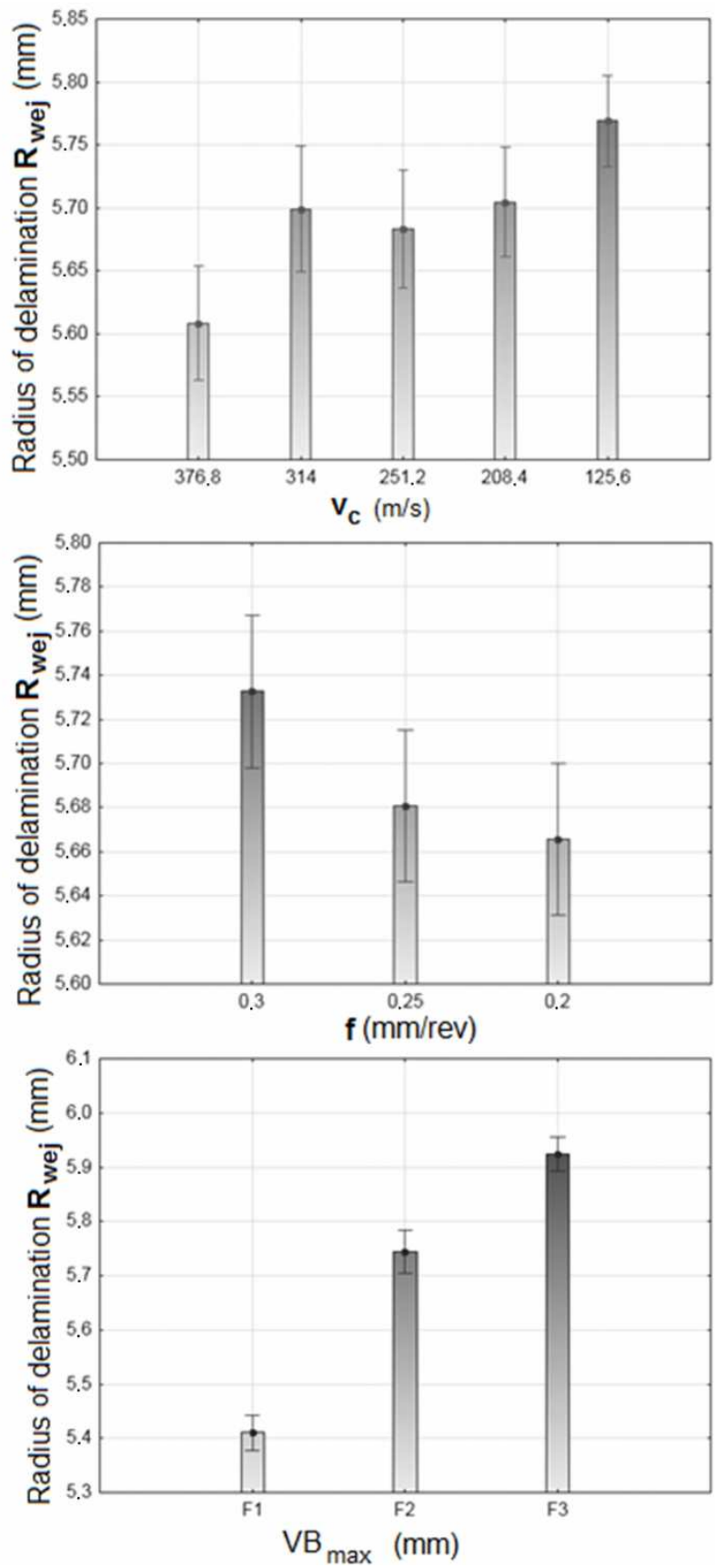

Fig. 4. The influence of cutting parameters on the value of the maximum radius of damage to the laminate at the entrance of the drill into the material $\left(R_{w e j}\right)$ 

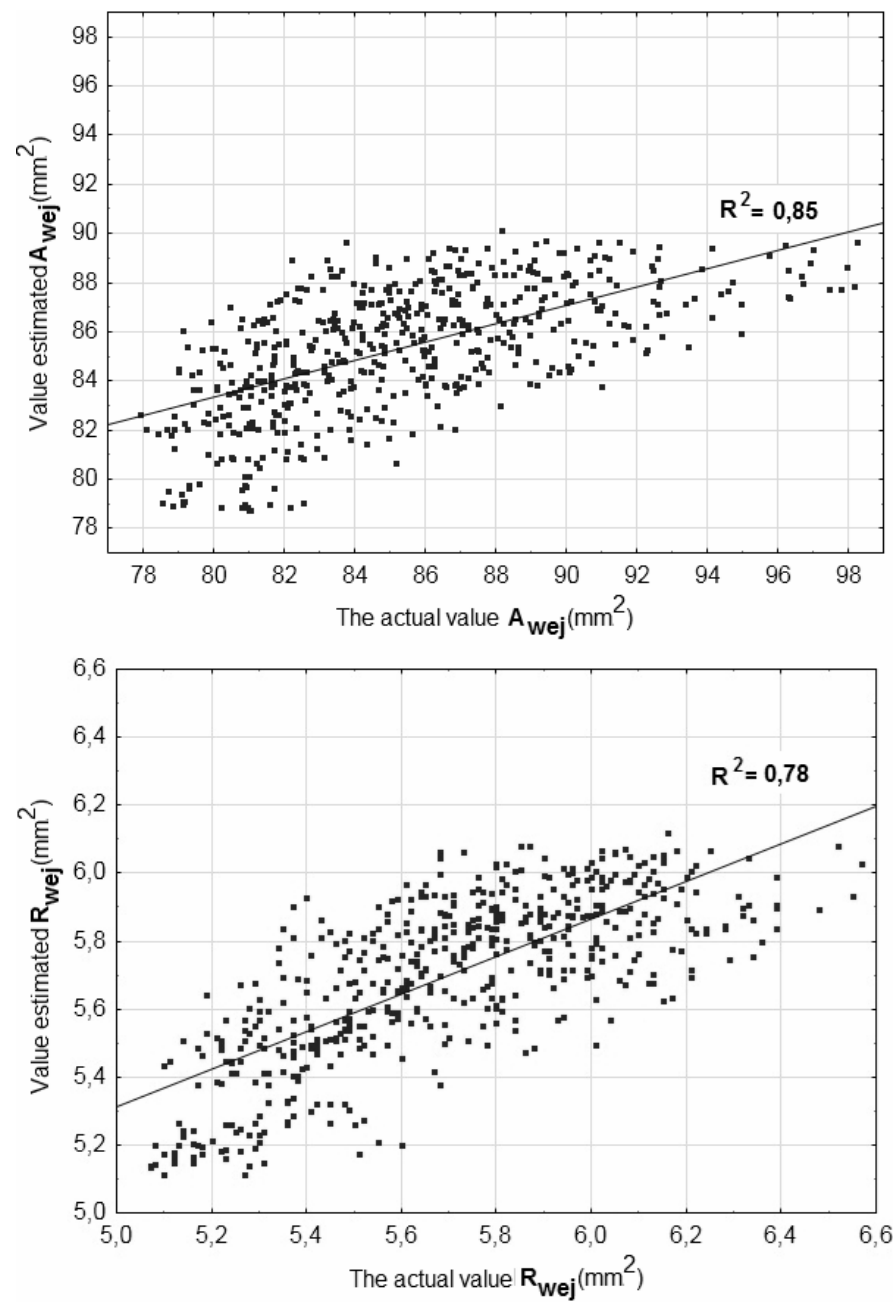

Fig. 5. Real and estimated values of the $A_{w e j}$ and $R_{w e j}$

The study presents an estimate of the maximum radius of delamination $\left(R_{w e j}\right)$ and the area of the delamination $\left(A_{w e j}\right)$ using linear regression:

$$
\begin{aligned}
& A_{w e j}=C_{F} \cdot V B_{\text {max }}^{x_{F}} \cdot f^{y_{F}} \cdot v_{c}^{z_{F}} \\
& R_{w e j}=C_{M} \cdot V B_{\max }^{x_{M}} \cdot f^{y_{M}} \cdot v_{c}^{z_{M}}
\end{aligned}
$$

where: $C_{F}, C_{M}$ - constants dependent on the processing conditions determined experimentally, $x_{F}, x_{M}$ - exponents characterizing influence of tool wear $V B_{\max }$, $y_{F}, y_{M}$ - exponents characterizing influence of feed rate $f, z_{F}, z_{M}$ - exponents characterizing influence of cutting speed $v_{c}$. 
This resulted in dependence described by eqs. (3) and (4):

$$
\begin{aligned}
& A_{w e j}=80.75+50.27 \cdot V B_{\max }-0.008 \cdot v_{c} \\
& R_{w e j}=5.22+3.83 \cdot V B_{\max }+0.35 \cdot f
\end{aligned}
$$

To verify the eqs. (3) and (4) a comparative analysis between the actual values, obtained in the study, and the estimated values was carried out, on the basis of these relationships. The results of this analysis are shown in fig. 5 .

\section{Conclusions}

Based on the results of analysis and eqs. (3) and (4) it can be seen that the maximum radius of delamination $\left(R_{w e j}\right)$ strongly depends on the tool wear and feed rates. The surface area of delamination $\left(A_{w e j}\right)$ depends on the tools wear and cutting speeds. Mathematical models have been proposed, using ANOVA, to assess the quality of the machined surface in the test cutting process.

\section{References}

[1] Davim J.P., Gaitonde V.N.: An investigative study of delamination in drilling of medium density fibre board (MDF) using response surface models, Int. J. Adv. Manuf. Technol., 37 (2008), 49-57.

[2] Davim J.P., Clemente V.: Evaluation of delamination in drilling medium density fiber board, J. Eng. Manuf., 221 (2007), 655-658.

[3] Gaitonde V.N., Karnik S.R.: Prediction and minimization of delamination in drilling of medium-density fiberboard (MDF) using response surface methodology and Taguchi design, Mat. Manuf. Processes, 23 (2008), 377-384.

[4] Palanikumar K., Prakash S.: Experimental investigation and analysis on delamination in drilling of wood composite medium density fiber boards, Mat. Manuf. Processes, 24 (2009), 1341-1348.

[5] Tsao C.: Thrust force and delamination of core-saw drill during drilling of carbon fiber reinforced plastics (CFRP), Int. J. Adv. Manuf. Technol., 37 (2008), 23-28.

[6] Zielińska-Szwajka J., Szwajka K.: The quality of the machined surface in the drilling process laminated chipboard, Forestry Wood Technol., 88 (2014), 248-254.

\section{CHROPOWATOŚĆ POWIERZCHNI PO WIERCENIU PEYTY WIÓROWEJ LAMINOWANEJ}

\section{Streszczenie}

W przeprowadzonych badaniach wykonano osiemnaście prób trwałościowych narzędzia dla różnych wartości analizowanych parametrów skrawania. Na podstawie wyników uzyskanych z przeprowadzonych badań określono wpływ wybranych parametrów skrawania na jakość po- 
wierzchni obrobionej. Zaproponowano modele matematyczne, wykorzystując analizę wariancji ANOVA, pozwalające oszacować jakość powierzchni obrobionej w badanym procesie skrawania.

Słowa kluczowe: wiercenie, zużycie narzędzia, jakość powierzchni, płyta wiórowa laminowana

DOI: $10.7862 / \mathrm{rm} .2015 .9$

Otrzymano/received: $10.10 .2014 \mathrm{r}$.

Zaakceptowano/accepted: 20.12.2014 r. 